\title{
Improvement of Trimethylamine Uptake by Euphorbia milii: Effect of Inoculated Bacteria
}

\author{
Dian Siswanto ${ }^{1,2}$, Paitip Thiravetyan ${ }^{2 *}$
}

\begin{abstract}
${ }^{1}$ Biology Department, Faculty of Mathematics and Natural Sciences, Brawijaya University, Malang, Indonesia ${ }^{2}$ Biotechnology Department, School of Bioresources and Technology, King Mongkut's University of Technology Thonburi, Bangkok, Thailand
\end{abstract}

\section{ABSTRACT}

In the last few years, a great emphasis has been placed on phytoremediation of indoor air pollution studies. However, limited work has been addressed to observe the bacteria potential to assist the phytoremediation process of trimethylamine (TMA). In this work, the ability of 4 different bacteria for TMA removal and IAA production were observed. Also, the enhancement of TMA removal efficiency by Euphorbia milii with various inoculating bacteria were investigated. Bacillus thuringiensis, Citrobacter amalonaticus Y19, Bacillus nealsonii, and white colony-soil bacteria (WCSB) were able to absorb TMA and produce IAA individually. B. thuringiensis and C. amalonaticus Y19 were the two most effective bacteria to improve TMA removal efficiency by the plant. Based on the highly correlation of bacterial IAA production with TMA removal efficiency by plants (in early periods of fumigation) and the highly correlation of bacterial IAA production with leaf IAA concentration of bacterially inoculated plants, two predicted mechanisms on improving TMA uptake are presented: (1) bacteria migration from plant roots to leaves increases leaf IAA concentration and (2) increasing concentration of bacterially inoculated root IAA inhibits transportation of IAA from leaves to roots, resulting in higher leaf IAA concentration. The concentration of leaf IAA is suggested to be a factor to increase stomatal opening which improves TMA removal efficiency of the plant.

Keywords: Trimethylamine (TMA), Euphorbia milii, indole-3-acetic acid, bacteria, absorption

\section{INTRODUCTION}

In the last few years, phytoremediation of indoor air pollution has obtained great emphasis. This environmentally-friendly, sustainable and aesthetically pleasing technology has been developed in a laboratory. However, it has several drawbacks such as limited tolerance to pollutant toxicity, limited removal ability to specific pollutant polarity and lengthy time needed for removal process [1]. Recently, a scientific study reported the potential of plants to remove the strong fishy odor of colorless, hygroscopic, and volatile trimethylamine (TMA). Besides its disturbance odor property, this pollutant can cause chronic harmful effects on humans $[2,3]$.

The study above showed a superior plant which was able to remove $100 \mathrm{ppm}$ of TMA in a closed system within only 12 hours [2]. The plant's ability to re-

\section{${ }^{*}$ Corresponding author:}

Paitip Thiravetyan

School of Bioresources and Technology, King Mongkut's

University of Technology Thonburi

126 Pracha Uthit Rd, Thung Khru, Bangkok, Thailand 10140

E-mail: paitip.thi@kmutt.ac.th move air pollutants cannot be separated from bacteria since these microorganisms natively exist and interact with plants. It is urgently required to find plant-associated bacteria which can accelerate phytoremediation. Bacteria support phytoremediation in several ways including through modulation of plant growth promoting parameters, provision of plant nutrients, production of secondary metabolites for plant disease control, and stand-alone absorption of pollutants by bacteria cells $[4,5]$.

Many scientific studies have shown the utilization of TMA as carbon and nitrogen sources by bacteria [ 3 , $6,7,8]$. Moreover, the TMA degradation pathway by bacteria under aerobic conditions has been proposed as follows: TMA $\rightarrow$ trimethylamine n-oxide $\rightarrow$ dimethylamine $\rightarrow$ methylamine $\rightarrow$ ammonia and formaldehyde. Further, formaldehyde may be conver-

\section{How to cite:}

Siswanto D, Thiravetyan P (2016) Improvement of trimethylamine uptake by Euphorbia milii: Effect of inoculated bacteria. J. Trop. Life. Science 6 (2): 123 - 130. 
ted to carbon dioxide and water [6-9]. However, the potential of bacteria to assist in the phytoremediation process of TMA removal has never been observed.

To improve the phytoremediation process, bacteria needs to occupy plants as their niches without causing pathological or physiological stress on them. Therefore, a suitable colonisations on or within the plant have to be provided. Indole-3-acetic acid (IAA) production can be used to screen and select competent bacteria for plant promoting agents [10]. The utilization of IAAproducing bacteria to enhance formaldehyde or benzene removal efficiency by plants has been investigated $[1,11]$. Inoculation of Bacillus cereus ERBP on 18-dayold naturally grown Clitoria ternatea seedlings improved its formaldehyde removal efficiency about 12 hours faster than non-inoculated plants [1]. Also, Enterobacter EN2 strain can improve the survival rate of Chlorophytum comosum under benzene exposure and also increases benzene removal efficiency of plants around 38 percent higher than sterilized plants [11].

In this study, the effect of bacteria (Bacillus thuringiensis, Bacillus nealsonii, unidentified white colony-soil bacteria (WCSB), and Citrobacter amalonaticus Y19) on TMA removal and IAA production were observed. In our previous study, Euphorbia milii was a crassulacean acid metabolism (CAM)-cycling plant which could potentially remove $100 \%$ of TMA in a closed system by its leaf and stem [12]. The effect of bacteria on TMA removal efficiency by $E$. milii was also investigated.

\section{MATERIALS AND METHODS}

\section{Bacteria sources}

Four bacteria species, B. thuringiensis, B. nealsonii, WCSB, and $C$. amalonaticus Y19 were utilized from Remediation Laboratory, King Mongkut's University of Technology Thonburi, Thailand. B. thuringiensis was isolated from fish-merchant waste; $B$. nealsonii was isolated from EM-4 (Effective Microorganism-4) solution; WCSB was isolated from TMA contaminated soil (resisted against five mM TMA in a liquid phase); $C$. amalonaticus Y19 was isolated from root E. milii following endophytic isolation protocol. Except WCSB, all the above bacteria species were identified by $16 \mathrm{~S}$ rRNA sequence analysis.

\section{Estimation of LAA production by bacteria}

IAA production by bacteria was estimated following the method described by Gordon and Weber [13] with minor modification. The isolated bacteria were grown in $100 \mathrm{~mL}$ of Nutrient Broth (NB) and incubated at $30^{\circ} \mathrm{C}$ on a rotary shaker. After 24 hours, the bacteria suspensions were concentrated by centrifugation at $4000 \mathrm{rpm}$ for 10 minutes, then supernatant of each suspension was removed. The pellet of bacteria cells was diluted with $10 \mathrm{~mL}$ of mineral medium without yeast extract and nitrogen $\left(2.5 \mathrm{~g} \mathrm{~K}_{2} \mathrm{HPO}_{4}, 1.0 \mathrm{~g} \mathrm{~K}_{2} \mathrm{HPO}_{4}\right.$, and $0.2 \mathrm{~g} \mathrm{MgSO}_{4} \cdot 7 \mathrm{H} 2 \mathrm{O}$ in $1 \mathrm{~L}$ of distilled water) and well mixed by vortex vibration. Further, $1 \mathrm{~mL}$ of each culture suspension was transferred into tubes containing $2 \mathrm{~mL}$ of the mineral medium with L-tryptophan as a supplement at a rate of $3.33 \mathrm{mg} \cdot \mathrm{mL}^{-1}$. The bacterial cultures were incubated at $30^{\circ} \mathrm{C}$ for two days. Colorimetric estimations of bacterial IAA were conducted on culture supernatant after centrifugation at $4000 \mathrm{rpm}$ for 10 minutes. $2 \mathrm{~mL}$ of supernatant was transferred to a new tube, and $4 \mathrm{~mL}$ of Salkowski's reagent was added to develop a pink color. After 20 minutes of color development, the absorbance was read at $530 \mathrm{~nm}$ using a spectrophotometer. IAA concentrations were calculated based on a calibration curve of pure IAA (SigmaAldrich) as a standard.

\section{TMA absorption by individual bacterium in volatile organic analysis (VOA) vials}

$2 \mathrm{~mL}$ of melted nutrient agar (NA) media was placed into a $42 \mathrm{~mL}$ VOA vial, then laid down to solidify NA along its vertical side. Further, $0.1 \mathrm{~mL}$ of $24-$ hour cultured bacteria in NB was injected and poured on the surface of NA inside the VOA vial. Bacterial isolate was incubated at $30^{\circ} \mathrm{C}$ for 3-4 days until bacteria colonies were grown and spread on all media surfaces. Three replicates were set for each bacterial isolate. Fumigation of TMA was conducted by preparing $750 \mathrm{ppm}$ of TMA in a chamber gas stock, then $5.6 \mathrm{~mL}$ of air was taken and injected into VOA vial to generate $100 \mathrm{ppm}$ of TMA. The experiment was conducted at $30 \pm 2^{\circ} \mathrm{C}$ and $760 \mathrm{mmHg}$ pressure. To assess the TMA concentrations, $4 \mathrm{~mL}$ of air was sampled at 4,8 and 12 hours from treated vials then analysed by a gas chromatography-flame ionization detector (GC-FID) with a $\mathrm{CP}-$ Volamine column. The injector and detector temperatures were $250^{\circ} \mathrm{C}$, while the column temperature was at $150^{\circ} \mathrm{C}$ isothermal.

\section{Inoculation of bacterial isolates to $E$. milii}

Each bacterial isolate was grown in $100 \mathrm{~mL}$ of NB and was kept on a shaker at $150 \mathrm{rpm}$ for 30 hours. Bacteria cells were harvested by centrifugation at 4000 rpm for 10 minutes. The supernatant was removed, and the total pellet of each isolate $(0.32 \pm 0.03$ grams $)$ was diluted with $50 \mathrm{~mL}$ Hoagland solution. $20 \mathrm{~mL}$ of 
bacteria suspension was poured onto soil (consisted of compost: coir pith at the ratio 1:1 w/w) near the plant stem (three month old plant); then the bacterially-inoculated plant was kept for two days. Control was provided as plant with $20 \mathrm{~mL}$ addition of Hoagland's solution. After two days, the soil was removed from the plants, except which was attached to roots. The plant roots with soil were wrapped with tissue paper and aluminum foil. Then, they were transferred into glass chambers for fumigation treatment.

\section{Fumigation experiments}

Plant fumigation was conducted using 15.6 L-glass chambers which were attached by two separate ports and equipped with rubber septum for TMA injection and gas chromatography sampling. Each plant with $130 \mathrm{~cm}^{2}$ leaf area was placed into a chamber and then closed and sealed with paraffin tape. $10.7 \mu \mathrm{L}$ of TMA ( $40 \%$ aqueous solution, analytical grade from Merck) was injected to generate a concentration of $100 \mathrm{ppm}$ inside the chamber. Control chambers without plant were also studied. The experimental conditions were 30 $\pm 2^{\circ} \mathrm{C}$ and $760 \mathrm{mmHg}$ pressure. Volatilization of TMA reaches equilibrium time at 4 hours [2]. Therefore, gas chromatography samples were initiated at 4 hours after TMA injection.

Calculation of TMA removal efficiency was conducted as follows:

$$
\text { TMA removal efficiency }(\%)=\frac{(C i-C f)}{C i} \times 100
$$

$C i \quad$ initial concentration of TMA (ppm)

Cf : final concentration of TMA (ppm)

\section{Gas analysis}

Measurements of TMA concentrations in treated and control were conducted by sampling $4 \mathrm{~mL}$ of air from the chambers. Then, the samples were analysed by gas chromatography.

\section{Estimation of IAA production by bacterially inoculated plant}

After TMA fumigation, 5 grams of plant leaves were ground and extracted with distilled water, 1:1 $(\mathrm{w} / \mathrm{v})$. The ground leaf suspensions were centrifuged at $4000 \mathrm{rpm}$ for 10 minutes. $1 \mathrm{~mL}$ of supernatant was diluted with $1 \mathrm{~mL}$ of distilled water; then the mixed suspension was transferred to a new tube, and $4 \mathrm{~mL}$ of Salkowski's reagent was added to develop a pink color. After 20 minutes of color development, the absorbance was read at $530 \mathrm{~nm}$ using a spectrophotometer. IAA concentrations were calculated based on a calibration curve of pure IAA (Sigma-Aldrich) as a standard.

\section{Total plate count of endophytic bacteria of uninocu- lated and bacterially inoculated plants}

For endophytic bacteria isolation, samples of root, stem and leaf were washed with distilled water to remove soil and dust particles. After that, plant samples were surface sterilized in $5 \% \mathrm{NaOCl}$ for $15 \mathrm{~min}$ and rinsed several times with sterile deionized water to ensure chemical removal. Serial dilutions were spread on nutrient agar plates, incubated for two days at $30^{\circ} \mathrm{C}$ and bacteria cell numbers were calculated.

\section{Denaturing gradient gel electrophoresis (DGGE) of bacteria communities within plant organs \\ A DCode ${ }^{\mathrm{TM}}$ Universal Mutation Detection System} (Bio-Rad Laboratories, USA) was used to conduct the DGGE technique. Genomic isolated DNA of 16S rRNA gene of $B$. thuringiensis (as the marker) or bacteria communities in plant root and stem extracts were amplified by PCR using universal primers. A $20 \mu \mathrm{L}$ aliquot from the PCR products, with an approximate weight of $250 \mathrm{ng}$, was loaded onto $8 \%$ (w/v) acrylamide gel, which contained a linear chemical gradient ranging from 45 to $65 \%$ denaturant $(7 \mathrm{M}$ urea and $40 \%$ $(\mathrm{v} / \mathrm{v})$ formamide). Electrophoresis proceeded at 80 Voltage for 16 hours at a temperature of $60^{\circ} \mathrm{C}$ in a DGGE chamber containing $0.5 \times$ TAE buffer.

\section{Statistical analysis}

One way analysis of variance (ANOVA) was used to analyze the data. Then, Duncan's multiple range tests using Statistical Program for Social Sciences (SPSS) with 95\% confidence was utilized.

\section{RESULTS AND DISCUSSION}

To improve the phytoremediation process, bacteria need to provide some endophytic traits such as the ability to colonize plants as their niches. Once they enter and live in plant tissues, they can potentially migrate from plant roots to stems and leaves $[14,15]$ and assist TMA uptake by aerial plant parts. In this study, bacteria competency as phytoremediation promoting agents was observed based on their cell ability to produce IAA and absorb TMA.

\section{Estimation of LAA production by bacteria}

Commonly, bacteria do not need to supply their cells with bacterial IAA although some bacteria can 
utilize IAA in the environment as nitrogen and carbon sources [16]. In a natural environment, bacteria produces IAA mainly to maintain their interaction with plants such as in pathogenesis, growth promotion and stress defence $[10,17]$. Most pathogenic bacteria produce IAA via the indole-3-acetamide (IAM) pathway (L-tryptophan $\rightarrow$ IAM $\rightarrow$ IAA). However, the most beneficial bacteria follows the indole-3-pyruvic (IPA) pathway (L-tryptophan $\rightarrow$ IPA $\rightarrow$ indole-3-acetaldehyde $\rightarrow$ IAA) [17-19].

Production of IAA by pathogenic bacteria in rhizosphere passes the host defense by interfering with IAA signaling in the plant. It potentially disturbs the cooperation of plant auxins and cytokinins to block several pathogenesis related-enzyme, including $\beta$-glucanase and chitinase at mRNA level [17]. Since the first step of bacteria invasion consists of the attachment of bacterial isolates onto epidermal cells of roots, it is logical to postulate that IAA producing bacteria, capable of improving plant root systems, have a higher probability of colonizing plant roots than other bacteria [10]. Moreover, bacterial IAA has also been reported to be able to avoid necrosis induction of plants as a hypersensitive response [17]. The role of bacterial IAA in plant root colonization does not only happen to pathogenic bacteria but also to plant growth promoting bacteria. In more detail, the plant growth promoting bacteria can utilize IAA to stimulate proliferation of plant tissues and thus enhance the colonization surface. Further, bacterial IAA can be used for loosening plant cell walls resulting in stimulation of nutrient exudation for bacteria growth, which results in increasing rhizosphere bacteria communities and improving colonization ability of bacteria [10].

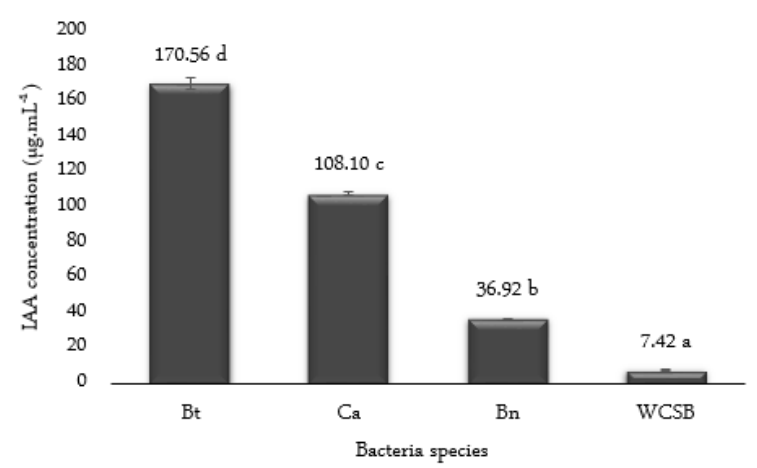

Figure 1. Estimation of produced IAA by bacteria. Bt: $B$. thuringiensis, Ca: C. amalonaticus Y19, Bn: $B$. nealsonii, WCSB: unidentified white colony-soil bacteria. Three replicates were provided. The same superscripted letters (a-d) are not significantly difffferent $(\mathrm{p}>0.05)$.
The estimation of IAA production by $B$. thuringiensis, C. amalonaticus Y19, B. nealsonii, and WCSB was investigated. It was shown that all bacterial isolates were able to produce IAA. Therefore, they had a high potential to colonize the roots of $E$. milii. The IAA production by bacteria from higher to lower concentration followed the sequence: $B$. thuringiensis $>C$. amalonaticus Y19 > B. nealsonii > WCSB (Figure 1). As above mentioned, the higher the IAA production, the easier it is for the bacterium to loosen the plant cell wall, and the easier it is for colonization to occur $[10,17]$.

The ability of $B$. thuringiensis to produce IAA highly corresponds to Vidal-Quist et al. [20]. They reported that all 44 tested $B$. thuringiensis could produce IAA. Although, the IAA productions may differ from our findings because the concentration of bacteria cells and supplemented L-tryptophan were different. Moreover, the 18 selected IAA-producing bacteria were tested and showed successful colonization on Arabidopsis thaliana roots. Several scientific studies have also reported $B$. nealsonii and $C$. amalonaticus as the isolated bacteria from plants with endophytic traits, assuming both can colonize the plants [21, 22]. However, due to the lack of information with regards to WCSB, its ability for plant colonization is still unclear.

\section{TMA absorption by individual bacterium in VOA vial}

Once bacteria successfully colonize plant roots, they can potentially help the plant absorb the pollutant [4]. These bacteria may indirectly improve TMA uptake by the plant through increasing plant leaf IAA production, thus increasing stomatal conductance of the plant. However, the bacteria may directly improve TMA uptake by the plant when they migrate to upper parts of the plant to absorb pollutants through their cells. Previous scientific studies have mainly focused on the utilization of bacteria (i.e. Aminobacter aminovorans, Paracoccus sp. T231, Paracoccus aminovorans, Pseudomonas aminovorans, Hyphomicrobium sp, and Micrococcus sp.) to remove TMA at liquid phase. Several bacteria have been reported to possess enzymes to degrade TMA to be formaldehyde and ammonia [9]. Recently, the potential to absorb TMA of individual bacteria have been studied by immobilizing Paracoccus sp. CP2 and Arthobacter sp. CP1 in a biofilter [8]. However, the TMA absorption investigation of individual bacterium including $C$. amalonaticus, $B$. thuringiensis, B.nealsonii, and WCSB is a novel study.

TMA uptake by the various individual bacterium is summarized in Table 1 . It shows that $C$. amalonaticus Y19, B. thuringiensis, and B. nealsonii were able to re- 
Table 1. TMA uptake by various bacteria within 4,8 , and 12 hours

\begin{tabular}{llll}
\hline \multirow{2}{*}{ Bacteria species } & \multicolumn{3}{c}{ Efficiency of TMA uptake (\%) } \\
\cline { 2 - 4 } & 4 hours & 8 hours & 12 hours \\
\hline
\end{tabular}

C. amalonaticus Y19 $83.57 \pm 0.62^{\mathrm{cA}} 83.78 \pm 0.89^{\mathrm{bA}} 85.13 \pm 3.37^{\mathrm{bA}}$

B. thuringiensis $\quad 79.07 \pm 0.06^{\mathrm{bA}} 80.62 \pm 0.33^{\mathrm{bAB}} 84.26 \pm 4.28^{\mathrm{bB}}$

B. nealsonii $\quad 76.53 \pm 2.59^{\mathrm{bA}} 82.55 \pm 1.10^{\mathrm{bAB}} 84.81 \pm 3.86^{\mathrm{bB}}$

WCSB $\quad 69.30 \pm 2.32^{\mathrm{aA}} 73.10 \pm 1.94^{\mathrm{aAB}} 76.09 \pm 2.21^{\mathrm{aB}}$

Note: The data is presented as mean \pm standard deviation of three individual experiments. Values in the same column with the same superscripted letters $(\mathrm{a}-\mathrm{c})$ are not significantly different $(\mathrm{P}>0.05)$. Values in the same row with the same superscripted letters $(A-B)$ are not significantly different $(\mathrm{P}>0.05)$.

move more than $84 \%$ of 100 ppm TMA in the VOA vial system within 12 hours. In the same period, lower TMA removal was observed for WCSB, which was able to remove around $76 \%$ of TMA. The ability of bacteria to remove TMA was highly correlated with possessed enzymes of the bacteria. TMA degrading bacteria possesses trimethylamine monooxygenase for aerobic degradation or trimethylamine dehydrogenase for anaerobic degradation or possesses both under aerobic conditions $[6,7]$.

\section{Removal of TMA by bacterially inoculated $E$. milii}

Bacteria inoculation on plants presented several improvements in plant TMA removal efficiencies starting at the 4th hour of the first cycle. The best improvement was shown by the plant with $B$. thuringiensis inoculation which removed $85 \%$ of 100 ppm TMA in the system. Although $C$. amalonaticus Y19 and WCSB showed less effect on plant TMA uptake during 4 hours than $B$. thuringiensis, all three bacteria could assist the plant in removing $100 \%$ of TMA during 16 hours. Plant inoculation with $B$. nealsonii produced the lowest improvement on plant TMA removal efficiency after the 4th hour of fumigation at the first cycle (Table 2).

The improvement of TMA removal efficiency by plants during 4 hours, from higher to lower, followed the sequence: plant $+B$. thuringiensis $>$ plant $+C$. amalonaticus Y19 > plant + B. nealsonii > plant + WCSB. The TMA removal efficiency highly correlated with the ability of individual bacterium to produce IAA and highly correlated with leaf IAA production by uninoculated and various bacterially inoculated plants. In this study, the IAA concentration with uninoculated and bacterially inoculated plant leaves from higher to lower concentration followed the sequence: plant with B. thuringiensis > plant with C. amalonaticus Y19 > plant with $B$. nealsonii > plant with $\mathrm{WCSB}>$ uninoculated plant (Figure 2). The concentrations of IAA production by an individual bacterium with IAA production by bacterially inoculated plants were also highly correlated.

IAA, the most abundant form of auxin, is synthesized mainly in young shoot tissues and transported to roots and other parts of the plant. At least two mechanisms of IAA transport have been reported in plants, one via the phloem from source to sink tissues and another by active polar auxin transport across membranes via auxin transport protein [23]. Considering the auxin transport routes and the potential endophytic migration of bacteria, two predicted mechanisms on improving TMA uptake by plants with bacteria inoculation are presented. Firstly, bacteria colonize plant roots then migrate to plant leaves and increase leaf IAA concentration to promote stomatal opening. Secondly, bacteria colonize plant roots then increase root IAA concentration thus inhibiting transportation of IAA from leaf to root. The inhibition results in higher leaf IAA concentration and increases stomatal opening. Willmer and Fricker [24] reported the function of IAA to promote stomatal opening in epidermal strips of Vicia faba under high utilization of $\mathrm{KCl}$ concentration in the incubation medium. IAA has also been found to reduce the stomatal closing effect of abscisic acid (ABA). The high concentration of IAA in the leaves potentially stimulates stomatal opening resulting in higher TMA

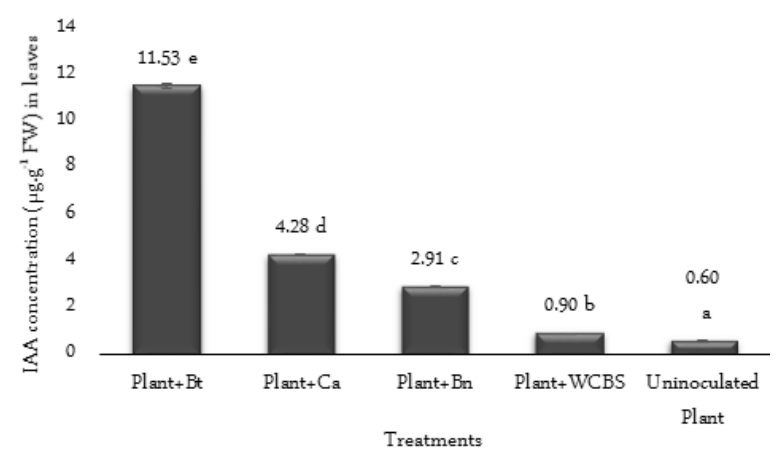

Figure 2. Estimation of produced IAA by plant with and without bacteria inoculation. Bt: B. thuringiensis, Ca: C. amalonaticus Y19, Bn: B. nealsonii, WCSB: unidentified white colony-soil bacteria. Three replicates were provided. The same superscripted letters (a-e) are not significantly different $(\mathrm{P}>0.05)$. FW: fresh weight. 
Table 2. Percentage of TMA removal efficiency by plants with and without bacteria inoculation

\begin{tabular}{|c|c|c|c|c|c|}
\hline Cycle 1 & \multicolumn{5}{|c|}{ Time (hours) } \\
\hline Condition & 4 & 8 & 12 & 16 & 20 \\
\hline Plant + Bt & $85.14 \pm 0.27^{\mathrm{e}}$ & $89.50 \pm 0.77^{c}$ & $96.12 \pm 0.50^{c}$ & $100.00 \pm 0.00^{b}$ & $100.00 \pm 0.00^{\mathrm{a}}$ \\
\hline Plant + Ca & $80.94 \pm 0.48^{\mathrm{d}}$ & $86.04 \pm 0.27^{b}$ & $97.57 \pm 1.33^{c}$ & $100.00 \pm 0.00^{b}$ & $100.00 \pm 0.00^{\mathrm{a}}$ \\
\hline Plant + Bn & $78.25 \pm 0.78^{c}$ & $81.43 \pm 0.51^{a}$ & $92.78 \pm 1.05^{b}$ & $97.34 \pm 1.36^{\mathrm{a}}$ & $100.00 \pm 0.00^{\mathrm{a}}$ \\
\hline Plant + WCSB & $77.43 \pm 0.20^{b}$ & $82.36 \pm 1.05^{\mathrm{a}}$ & $94.21 \pm 1.10^{b}$ & $100.00 \pm 0.00^{b}$ & $100.00 \pm 0.00^{\mathrm{a}}$ \\
\hline Uninoculated plant & $72.06 \pm 0.41^{\mathrm{a}}$ & $82.77 \pm 1.09^{\mathrm{a}}$ & $89.10 \pm 0.61^{a}$ & $96.99 \pm 0.25^{\mathrm{a}}$ & $100.00 \pm 0.00^{\mathrm{a}}$ \\
\hline Cycle 2 & \multicolumn{5}{|c|}{ Time (hours) } \\
\hline Condition & 24 & 28 & 32 & 36 & 40 \\
\hline Plant + Bt & $57.22 \pm 0.48^{c}$ & $87.91 \pm 2.29^{\mathrm{d}}$ & $90.85 \pm 0.87^{\mathrm{e}}$ & $100.00 \pm 0.00^{c}$ & $100.00 \pm 0.00^{\mathrm{a}}$ \\
\hline Plant $+\mathrm{Ca}$ & $61.15 \pm 1.76^{\mathrm{d}}$ & $83.76 \pm 0.69^{c}$ & $87.93 \pm 1.11 \mathrm{~d}$ & $100.00 \pm 0.00^{c}$ & $100.00 \pm 0.00^{\mathrm{a}}$ \\
\hline Plant + Bn & $40.56 \pm 0.84^{\mathrm{a}}$ & $74.46 \pm 1.45^{\mathrm{a}}$ & $77.70 \pm 0.23^{a}$ & $92.62 \pm 0.58^{\mathrm{a}}$ & $100.00 \pm 0.00^{\mathrm{a}}$ \\
\hline Plant + WCSB & $48.18 \pm 0.54^{c}$ & $79.84 \pm 0.58^{b}$ & $83.85 \pm 0.58^{c}$ & $95.98 \pm 1.57^{b}$ & $100.00 \pm 0.00^{\mathrm{a}}$ \\
\hline Uninoculated plant & $46.09 \pm 1.52^{b}$ & $77.94 \pm 0.57^{b}$ & $81.21 \pm 0.43^{b}$ & $94.68 \pm 0.98^{b}$ & $100.00 \pm 0.00^{\mathrm{a}}$ \\
\hline Cycle 3 & \multicolumn{5}{|c|}{ Time (hours) } \\
\hline Condition & 44 & 48 & 52 & 56 & 60 \\
\hline Plant $+\mathrm{Bt}$ & $65.46 \pm 2.23^{\mathrm{d}}$ & $70.24 \pm 1.75^{\mathrm{d}}$ & $81.74 \pm 2.78^{c}$ & $89.02 \pm 1.25^{\mathrm{d}}$ & $91.30 \pm 1.03^{b}$ \\
\hline Plant + Ca & $55.21 \pm 2.95^{c}$ & $58.94 \pm 2.18^{c}$ & $74.42 \pm 1.55^{b}$ & $82.11 \pm 1.15^{c}$ & $91.79 \pm 2.68^{b}$ \\
\hline Plant + Bn & $27.76 \pm 0.38^{\mathrm{a}}$ & $42.23 \pm 1.37^{\mathrm{a}}$ & $66.10 \pm 2.88^{\mathrm{a}}$ & $73.56 \pm 0.62^{a}$ & $86.68 \pm 0.70^{a}$ \\
\hline Plant + WCSB & $45.22 \pm 1.38^{b}$ & $59.01 \pm 0.91^{c}$ & $75.26 \pm 0.21 b$ & $79.97 \pm 1.72^{b}$ & $91.92 \pm 2.48^{b}$ \\
\hline Uninoculated plant & $44.16 \pm 2.00^{b}$ & $50.64 \pm 0.39^{b}$ & $68.96 \pm 0.51^{a}$ & $75.01 \pm 1.34^{\mathrm{a}}$ & $86.52 \pm 1.23^{a}$ \\
\hline Cycle 3 (cont.) & \multicolumn{2}{|c|}{ Time (hours) } & & & \\
\hline Condition & 64 & 68 & & & \\
\hline Plant $+\mathrm{Bt}$ & $95.76 \pm 0.33^{d}$ & $100.00 \pm 0.00^{c}$ & & & \\
\hline Plant $+\mathrm{Ca}$ & $93.57 \pm 0.48^{c}$ & $100.00 \pm 0.00^{c}$ & & & \\
\hline Plant + Bn & $88.99 \pm 0.80^{b}$ & $94.99 \pm 0.80^{b}$ & & & \\
\hline Plant + WCSB & $93.53 \pm 0.07^{c}$ & $100 \pm 0.00^{c}$ & & & \\
\hline Uninoculated plant & $87.55 \pm 0.35^{\mathrm{a}}$ & $93.55 \pm 0.35^{\mathrm{a}}$ & & & \\
\hline $\begin{array}{l}\text { The data is } \\
\text { the same s }\end{array}$ & $\begin{array}{l}\text { ented as mean } \pm \\
\text { cripted letters }\end{array}$ & $\begin{array}{l}\text { adard deviation } \\
\text { are not significan }\end{array}$ & $\begin{array}{l}\text { ree individual e } \\
\text { lifferent }(\mathrm{P}>0 \text {. }\end{array}$ & ments. Values in & $\begin{array}{l}\text { same column with } \\
\text { Ca: C. amalonaticus }\end{array}$ \\
\hline
\end{tabular}

removal efficiency of the plant. Also, once bacteria migrate to plant leaves, they can absorb TMA through their cells.

The second cycle of TMA fumigation was initiated by re-injecting $100 \mathrm{ppm}$ of TMA to observe the sustainability of plant TMA uptake. At the 4th hour, inoculated bacteria continuously improved TMA removal by plant compared to the control, except the $B$. nealsonii which showed a negative impact. Only $B$. thuringiensis and C. amalonaticus Y19 still possessed a significant positive effect on plant TMA removal efficiency at the 16th hour of TMA fumigation. This phenomenon was still present at the third cycle until the 28th hour of TMA fumigation (Table 2).

The three cycles of TMA removal by bacterially in- oculated E. milii indicated that the ability of bacteria to produce IAA and bacterially-self absorbing TMA was highly correlated with the efficiency of TMA removal by plant at early periods of fumigation. Although the TMA removal efficiency by plants tends to decrease over the time of fumigation from the first cycle to the third cycle, the improvement effect of inoculated bacteria on plant TMA removal efficiencies was remain until the end of the third cycle.

\section{Endophytic bacteria of uninoculated and bacterially in- oculated plants}

The effect of inoculated bacteria on bacteria communities within plants was investigated by isolating endophytic bacteria from surface sterilized bacterially in- 
Table 3. Viable endophytic bacteria of uninoculated and selected bacterially inoculated plant

\begin{tabular}{|c|c|c|c|}
\hline \multirow{2}{*}{$\begin{array}{l}\text { Plant } \\
\text { organ }\end{array}$} & \multicolumn{3}{|c|}{ Number of bacteria (CFU.g $\left.{ }^{-1} \mathrm{FW}\right)$} \\
\hline & $\begin{array}{l}\text { Plant }+B \text {. } \\
\text { thuringiensis }\end{array}$ & $\begin{array}{c}\text { Plant }+C . \\
\text { amalonaticus Y19 }\end{array}$ & $\begin{array}{c}\text { Uninoculated } \\
\text { plant }\end{array}$ \\
\hline Root & $1.16 \pm 0.07 \times 10^{5 \mathrm{cA}}$ & $5.00 \pm 1.41 \times 10^{5 \mathrm{cB}}$ & $4.70 \pm 0.42 \times 10^{5 \mathrm{cB}}$ \\
\hline Stem & $3.85 \pm 0.21 \times 10^{3 \mathrm{bA}}$ & $3.70 \pm 0.42 \times 10^{4 \mathrm{bB}}$ & $4.00 \pm 0.00 \times 10^{4 \mathrm{bB}}$ \\
\hline Leaf & $<1.00 \times 10^{1 \mathrm{aA}}$ & $5.00 \pm 0.00 \times 10^{1 \mathrm{aB}}$ & $5.00 \pm 0.00 \times 10^{1 \mathrm{aB}}$ \\
\hline ote: & \multicolumn{3}{|c|}{$\begin{array}{l}\text { The data is presented as mean } \pm \text { standard deviation } \\
\text { of three individual experiments. Values in the same } \\
\text { column with the same superscripted letters }(\mathrm{a}-\mathrm{c}) \text { are } \\
\text { not significantly different }(\mathrm{P}>0.05) \text {. Values in the } \\
\text { same row with the same superscripted letters }(\mathrm{A}-\mathrm{B}) \\
\text { are not significantly different }(\mathrm{P}>0.05) \text {. FW: fresh } \\
\text { weight. }\end{array}$} \\
\hline
\end{tabular}

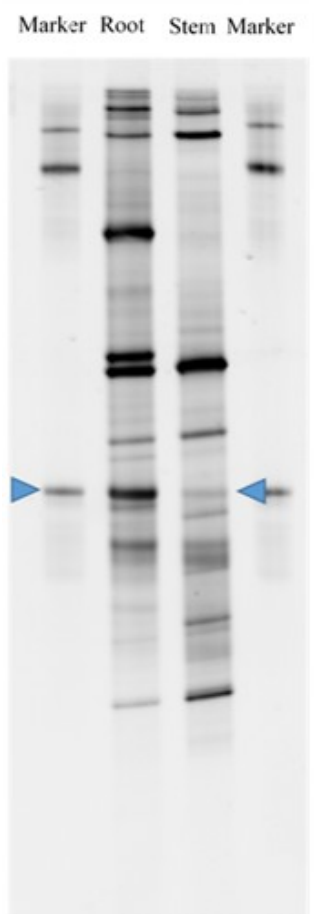

Figure 3. DGGE result of marker (pure B. thuringiensis) and bacterially inoculated plant root and stem. The triangles indicated the predicted $B$. thuringiensis within plant organs based on the marker band.

oculated plants. Total plate count method was performed to predict the endophytic bacteria community within plant roots, stems and leaves, although the bacteria number of each colony was not separated. The viable endophytic bacteria of uninoculated and inoculated plants by $B$. thuringiensis are shown in Table 3 .

DGGE analysis was performed to confirm the presence of living $B$. thuringiensis within root and stem of plants. Pure amplified 16S rRNA gene fragments of the marker, which consisted of a pure B. thuringiensis, produced three different bands in the electrophoresis gel (Figure 3). The bacteria communities within plant root and stem produced several bands in which one of them had similar distance with the third band of $B$. thuringiensis and highly corresponded with the findings of Ramnath et al. [25]. This result suggested that living $B$. thuringiensis was available within root and stem of plants although the bacteria numbers within the plant root might be higher than plant stem since the predicted band of targeted bacteria was available in high intensity within the root and available in low intensity within the stem of E. milii (Figure 3).

$B$. thuringiensis inoculation onto E. milii likely suppressed endophytic bacteria communities within plants compared to uninoculated plants and C. amalonaticus Y19 inoculated plants. Perhaps, the suppression phenomena are caused by Zwittermicin A production by B. thuringiensis. Zwittermicin $\mathrm{A}$ is a linear aminopolyol, highly polar, and water soluble antibiotic which works mainly against gram-negative and pathogenic bacteria at moderate activity [26]. The suppression of endophytic bacteria communities within E.milii by $B$. thuringiensis (non-native bacteria of $E$. milii) might induce biotic-stress on plants, thus producing more plant IAA. However, the disturbance of bacteria community within plants did not appear on C. amalonaticus Y19 inoculation since this bacteria is native bacteria of $E$. milii roots. As above mentioned, IAA concentration in leaves of $B$. thuringiensis inoculated plants was much higher compared to $C$. amalonaticus Y19 inoculated plants and uninoculated plants. However, further study of this biotic stress phenomena is urgently required since it will influence the sustainability of TMA removal efficiency by $B$. thuringiensis inoculated plants.

\section{CONCLUSION}

B. thuringiensis, C. amalonaticus Y19, B. nealsonii, and WCSB were able to produce IAA and absorb TMA. Except B. nealsonii, inoculation of bacteria on plants successfully improved the efficiency of TMA removal by plants from the first cycle until the third cycle of TMA fumigation. Furthermore, the high concentration of IAA in the leaf is suggested to be a factor to increase stomatal opening which improves TMA removal efficiency of the plant. The plate count method and DGGE analysis suggested that living $B$. thuringiensis was available within root and stem of bacterially inoculated plants which indicated successful inoculation of bacteria. 


\section{ACKNOWLEDGMENT}

The authors would like to thank the Directorate General of Higher Education (DGHE) of Indonesia Scholarship for financially supporting Mr. Dian Siswanto.

\section{REFERENCES}

1. Khaksar G, Treesubsuntorn C, Thiravetyan P (2016) Endophytic Bacillus cereus ERBP - Clitoria ternatea interactions: Potentials for enhancement of gaseous formaldehyde removal. Environ Exp Bot 126: 10-20.

2. Boraphech P, Thiravetyan P (2015) Removal of trimethylamine (fishy odor) by C3 and CAM plants. Environ Sci Pollut R 22: 11543-11557.

3. Liffourrena A, Lucchesi G (2014) Degradation of trimethylamine by immobilized cells of Pseudomonas putida A (ATCC 12633). Int Biodeter Biodegr 90: 88-92.

4. Ma Y, Prasad MNV, Rajkumar M et al. (2011) Plant growth promoting rhizobacteria and endophytes accelerate phytoremediation of metalliferous soils. Biotechnol Adv 29: 248-258.

5. Hardoim PR, Overbeek LS van, Elsas JD van (2008) Properties of bacterial endophytes and their proposed role in plant growth. Trends Microbiol 16(10): 463-471.

6. Kim SG, Bae HS, Lee ST (2001) A novel denitrifying bacterial isolate that degrades trimethylamine both aerobically and anaerobically via two different pathways. Arch Microbiol 176: 271-277.

7. Kim SG, Bae HS, Oh HM et al. (2003) Isolation and characterization of novel halotolerant and/or halophilic denitrifying bacteria with versatile metabolic pathways for the degradation of trimethylamine FEMS Microbiol Lett 225: 263-269.

8. Ho KL, Chung YC, Lin YH et al. (2008) Biofiltration of trimethylamine, dimethylamine, and methylamine by immobilized Paracoccus sp. CP2 and Arthrobacter sp. CP1. Chemosphere 72: 250-256.

9. Rappert S, Müller R (2005) Microbial degradation of selected odorous substances. Waste Manage 25: 887-907.

10. Etesami H, Alikhani HA, Hosseini HM (2015) Indole-3acetic acid (IAA) production trait, a useful screening to select endophytic and rhizosphere competent bacteria for rice growth promoting agents. MethodsX 2: 72-78.

11. Sriprapat W, Thiravetyan P (2016) Efficacy of ornamental plants for benzene removal from contaminated air and water: Effect of plant associated bacteria. Int Biodeter Biodegr. In Press.

12. Siswanto D, Chhon Y, and Triravetyan P (2016) Uptake and degradation of trimethylamine by Euphorbia milii. Environ Sci Pollut Res. In Press.

13. Gordon SA, Weber RP (1951) Colometric estimation of indolacetic acid. Plant Physiol 26: 192-195.

14. Tanuja, Bisht SC, Mishra PK (2013) Ascending migration of endophytic Bacillus thuringiensis and assessment of benefits to different legumes of N.W. Himalayas. Eur J Soil Biol 56: 56-64.

15. Shin MN, Shim J, You Y et al. (2012) Characterization of lead resistant endophytic Bacillus sp. MN3-4 and its potential for promoting lead accumulation in metal hyperaccumulator Alnus firma. J Hazard Matter 199-200:314-320

16. Leveau JHJ, Lindow SE (2005) Utilization of the plant hormone indole-3-acetic acid for growth by Pseudomonas putida strain 1290. Appl Environ Microb 71 (5): 23652371.

17. Spaepen S, Vanderleyden J, Remans R (2007) Indole-3acetic acid in microbial and microorganism-plant signaling. FEMS Microbio Rev 31: 425-448.

18. Kawaguchi M, Syono K (1996) The excessive production of indole-3-acetic acid and its significance in studies of biosynthesis of this regulator of plant growth and development. Plant Cell Physiol 37(8): 1043-1048.

19. Kasan K (2013) Auxin and the integration of environmental signals into plant root development. Annals of Botany. 11 pages. doi:10.1093/aob/mct229.

20. Vidal-Quist JC, Rogers HJ, Mahenthiralingam E et al. (2013) Bacillus thuringiensis colonises plant roots in a phylogeny-dependent manner. FEMS Microbiol Eco 86: 474-489.

21. Bahgat MMM, Kawasthy SA, Bous MME et al. (2014) Characterization of endophytic bacteria isolated from medicinal plant Capparissinaica Veill. and analyze its bioactive flavonoid. Indian Journal of Applied Research 4 (11): 5-13.

22. Tan ZY, Peng GX, Xu PZ et al. (2009) Diversity and high nitrogenase activity of endophytic diazotrophs isolated from Oryza rufipogon Griff. Chinese Sci Bull 54: 28392848.

23. Grunewald W, Noorden GV, Isterdael GV et al. (2009) Manipulation of auxin transport in plant roots during Rhizobium symbiosis and nematode parasitism. The Plant Cell 21: 2553-2562.

24. Willmer C, Fricker M (1996) Stomata. Second edition. Editors: M. Black and B. Charlwood. London, Springer-Science+Business Media.

25. Ramnath L, Tamara B, Govinden R (2014) Method optimization for denaturing gradient gel electrophoresis (DGGE) analysis of microflora from Eucalyptus sp. wood chips intended for pulping. African journal of biotechnology 13(3): 256-265.

26. Sansinenea E, Ortiz A (2013) An antibiotic from Bacillus thuringiensis against Gram-negative bacteria. Biochem \& Pharmacol 2: 1-2. 